\title{
NIH heads for 7.1 per cent budget growth
}

[WASHINGTON] A joint spending committee of the US Senate and House of Representatives last week approved a 7.1 per cent funding increase for the National Institutes of Health (NIH) - to $\$ 13.65$ billion - in the fiscal year 1998, in a bill reconciling differences between the two legislative bodies.

Such a bill would normally move speedily to the floor of the House and then the Senate for final passage. But as soon as the politicians had signed off the massive bill last Thursday (30 October) it became captive to a sharp feud between Republican factions in Congress, and between Congress and the White House, over an unrelated education measure it contains concerning national examinations in reading and mathematics.

As a result, Newt Gingrich (Republican, Georgia), the Speaker of the House, barred the bill from proceeding to the House floor. At the beginning of this week, it was unclear whether Gingrich would order the reopening of negotiations on the \$269-billion bill, which funds the Departments of Labor, Health and Human Services, and Education.

According to John Porter (Republican, Illinois), who chairs the House appropriations subcommittee responsible for $\mathrm{NIH}$ funding, a likely alternative is that the bill will be bundled together with several other outstanding spending bills containing equally controversial measures. These would go to a single vote on the House floor, perhaps as early as this week.

As it contains so many spending provisions, such an 'omnibus' bill would be intended to force politicians to "swallow hard and pass it”, says David Moore, a lobbyist for the Association of American Medical Colleges. It would also make it more difficult for the White House to veto the larger bill.

Whatever the outcome of the impasse on examinations, Porter said last Friday that he was confident that the NIH increase is secure. "Unless there is a complete breakdown, which I don't contemplate, NIH will receive a 7.1 per cent increase for the next fiscal year," he said.

The earlier House version of the appropriations bill had contained a 6 per cent increase for NIH, while its Senate counterpart had sought 7.5 per cent. The committee's bill also provides the NIH with authority to spend $\$ 100$ million on research into Parkinson's disease in 1998, and allocates nearly \$17 million to begin construction of an AIDS vaccine research centre - reduced from an earlier House figure of \$26.1 million.
In another change, Tom Harkin (Democrat, Iowa) succeeded in boosting by twothirds the budget of NIH's controversial Office of Alternative Medicine (see Nature $389,652 ; 1997)$. The bill as approved by the committee provides $\$ 20$ million to the office. Its current budget is $\$ 12$ million and NIH's director, Harold Varmus, had called for that to be cut to $\$ 7.5$ million.

Also last Friday, Porter repeated his intention to seek an additional \$2.5- \$3 billion for NIH in 1999 as part of a drive to double its budget over the next five years. The increase could be funded, he said, by government revenues that had not been anticipated during the drafting of a balanced budget agreement that set tight caps on such new spending.

"There may be some very strong rationale for varying to some degree the balanced budget agreement to allow us to have this initiative on research," said Porter. "Given the good economy, it's a good time to propose it."

But he added that he was willing to drop the idea if NIH leaders feel that such a large, quick increase would overwhelm their capacity to deal efficiently and effectively with it. "We don't want to give them money they can't use wisely and for good research," he said.

\section{Canada 'still has a long way to go' in effective control of acid rain}

[MONTREAL] Large areas of North America will have to cut sulphur dioxide emissions by an additional three-quarters if they are to control acid rain - a problem many believed to be a thing of the past.

A report published last month by the Acidifying Emissions Task Group, set up by the Canadian government, concludes that this extra cut in emissions is needed in the Canadian provinces of Ontario and Quebec and in midwest and eastern parts of the United States.

The task group, made up of representatives of government, industry and environmental and health groups, was responding to a 1994 request from Canadian environment and energy ministers for a strategy to mitigate the environmental and health effects of acid rain.

"The assumption has been that the problem is solved," says Wayne Draper, a senior official in the federal environment department who acts as joint chairman of the group. "In reality, we took only a first step and we still have a long way to go."

That first step, however, has already halved sulphur dioxide $\left(\mathrm{SO}_{2}\right)$ emissions in seven eastern provinces. Begun in 1985, the Eastern Canada Acid Rain Program's goal was to reduce wet sulphate deposition to no more than $20 \mathrm{~kg}$ per hectare per year. A

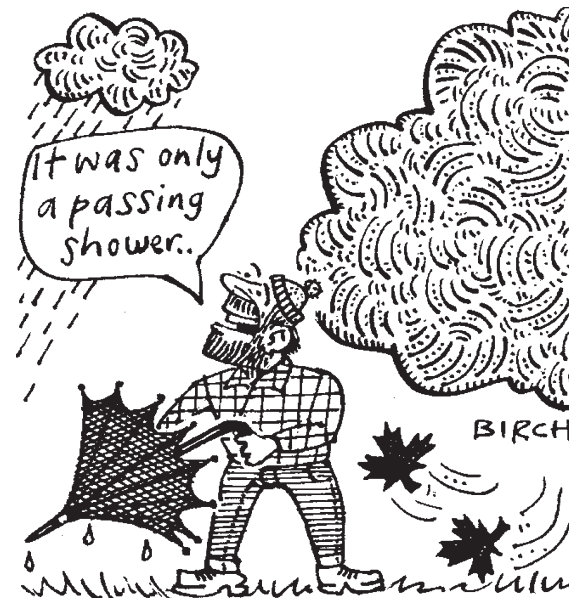

smaller Sulphur Oxide Management Area in the southeast was to cap $\mathrm{SO}_{2}$ emissions at 1.75 million tonnes a year starting in 2000 .

Last year, emissions were already 29 per cent below that cap.

The United States has cut emissions by 30 per cent since 1980 , and by 2010 , when its acid rain programme is fully implemented, emissions should be down by 40 per cent. But this will still leave US emissions about five times greater than those from Canada and responsible for more than half the total acid deposition in eastern Canada.

"Even in 2010, with full implementation of the Canadian and US programs, almost 800,000 square kilometres in southeastern Canada - an area the size of France and the United Kingdom combined - will receive harmful levels of acid rain; that is, levels above critical load limits for aquatic systems," says the report, Towards a National Acid Rain Strategy.

Tests show that, while sulphate levels are declining in most lakes in Ontario and Quebec and are stable in the Atlantic region, acidity levels remain high. Only 33 per cent of 202 lakes tested in Ontario, Quebec, Nova Scotia and Newfoundland between the early 1980s and the mid-1990s contained less acid, 11 per cent had more and 56 per cent showed the same levels.

"Acidified lakes pose a serious threat to biodiversity in eastern Canada," says the report. "Loons do not breed as easily or lay as many eggs, and there are fewer species of clams and crayfish - an integral part of the food chain."

The group recommends negotiating with the United States for further reductions, and reviewing related science, research and monitoring programmes. The report will go to a meeting of energy and environment ministers later this month, who will try to propose a national acid rain strategy.

David Spurgeon 